\title{
Education for organising in a hot climate: a manufacturing union's experience
}

\begin{abstract}
: (152 words)
This paper reports on research into a national education program within one of Australia's largest trade unions. The program was designed to assist the union's staff and elected officials respond to the rapidly changing industrial and political conditions in the manufacturing sector. It is ambitious in scope comprising sixteen modules that range from organising skills to union history and political consciousness. Participants are expected to complete formal work-related assessment in order to satisfy the module requirements, and thereby become eligible for an increase in pay. However, there has been a low number of assessment exercises completed and strong resistance to the idea of linking pay increases to course completion. The paper reports on research conducted with select groups of the union's staff focussing on the program's effectiveness, participant experience, assessment issues, and the challenges involved in meeting different learning needs. Finally it discusses possible improvements to the program arising from the research.
\end{abstract}


(7,023 words)

\section{Educating for organising in a hot climate: a manufacturing union's experience}

What learning needs do appointed and elected staff employed by unions have in the neoliberal industrial and economic world? What sort of education program does a large national trade union need to equip its officers and officials to work successfully in a rapidly changing industrial environment? What challenges face the union in introducing such a change and how does it know whether it is meeting the needs it has identified? These are some of the questions that the Manufacturing Union confronted when it embarked on an overhaul of the education and training that it provided for its officers and officials in 2003.

The Manufacturing Union (MU) is one of Australia's oldest and strongest unions. Established in the $19^{\text {th }}$ century by British immigrant workers it was originally a skilled craft union that has evolved as a result of various amalgamations. It has consistently set the industrial pace for wages and conditions, and has been widely recognised throughout its existence as the leading militant or left wing union in the country.

The physical environments in which MU members work include factories, workshops, building sites, mines, airports, shipyards, laboratories and offices. The industries covered include metals and engineering, mechanical maintenance, vehicles, printing and paper making, food and confectionary, architecture, chemistry, science, surveying and drafting. Members include production workers, tradespeople, supervisors, some administrative workers and some professionals.

Like many unions the MU has experienced difficult times in retaining membership numbers, income and most importantly membership density in the industry. Changes in the 
way goods are produced and traded, massive changes in the way technology has increased productivity combined with constant efforts to increase the intensity of work has resulted in a significant reduction in the number of people employed in the manufacturing sector. Employment has moved from manufacturing and primary production to service industries, where the proportion of workers employed in manufacturing dropped from 30.4 percent in 2000, to 27.3 percent in 2001, and 25.7 percent in 2002 (ABS 2002). Added to these structural changes has been a failure to recruit members working in new areas in manufacturing including greenfield sites.

In 1991 the union commenced a series of mergers with other unions and over the next four years four unions amalgamated to form the MU. After each merger the union's numbers increased and in 1995 there were 204,000 members. However in the following seven years numbers consistently fell so that by 2002 there were 150,000 members. Over that same period the union's finances suffered as membership contributions fell but expenditure stayed higher than income. During the year 2000 expenditure exceeded contributions by \$12 million. (Corrie, 2003, 100)

The introduction of the Workplace Relations Act in 1996 by the newly elected conservative government also radically changed the institutional framework that had previously fostered union recruitment. The outlawing of closed shops, restrictions on the rights of union officials to enter workplaces, and a curtailing of issues that unions could organise around made the job of recruiting members much more difficult and led unions such as the MU to begin re-thinking organising strategies and practices. 
In the decade from 1992-2002 the union's density fell from 44 per cent to 27 percent. (ABS 2003) Density, or the number of members as a proportion of the total number of workers in the industry, is now seen as being a more important indicator of influence than raw member numbers. Falling density not only means lower confidence and morale, more importantly it means a reduced ability to exercise power in the workplace and the industry thereby jeopardising improved wages, conditions and job security.

Confronted by these challenges the union introduced a new national education program for its officers and officials in 2003. The MU approach reflects the most thorough commitment to structured formal training within the union movement. Since Competency Based Training found its strongest adherents within manufacturing during the training reform years it is no surprise to find the MU extending it into its own training program. Among Australian trade unions similar formally accredited competency based programs have been introduced. However, not all unions have embraced formal competency based programs to educate and train their officers. Others, including those committed to the organising model, are looking at combinations of formal programs and informal work-based learning, where regular individual and team debriefing occurs, focused seminars on organising, industry research, planning are held, and where concepts such as developing Communties of Practice are under consideration. The debate around the most effective approach to union education in the current political and economic climate is being carried out in a number of countries. (Ball 2003; Burke et al 2002; Carter and Cooper 2002; Crosby 2005; Delp et al 2002; Fletcher 1998; Griffin \& Moors 2002; and Kopsen \& Larsen 2002)

The MU employs over 200 staff working in State branches and a National Office in Melbourne. It employs Organisers, Lead Organisers, Industrial Officers, specialist staff in 
Research, Legal and Occupational Health \& Safety and administrative staff. It was an ambitious program that was part of a broader strategy that included prioritising organising, leadership development, accountability and integrating internal management systems, withthe aim of developing 'effective, informed, mindfully militant organisers and other officials’. (Sutherland 2003) It represented a significant expansion of educational provision within the union.

In early 2005 the union leadership decided to put much of the program on hold while a formative evaluation was undertaken. A number of problems had emerged that led the union to institute the review. Some, such as a lack of administrative support, had been rectified with the appointment of staff to the education unit. Other problems included a poor rate of submission of course assessments, the cancellation of too many courses - one third of all courses had been cancelled in the previous fifteen months, - a hostile response on the part of a number of staff to the link between course completion and pay increases, and some disaffection with the recognition of prior learning (RPL) process. In addition there was a feeling that courses were too long and some staff were reporting difficulty in getting release from their positions to attend. These were leading to inefficiencies for the union and the program and meant that the program might not be able to deliver the outcomes the union leadership had hoped for.

This paper reports on research conducted with select groups of the union's staff focussing on the program's effectiveness, participant experience, assessment issues, and the challenges involved in meeting different learning needs. It provides an opportunity to understand the development of a particular type of union education program, the reaction to it 
from officers and officials within the union, so that comparisons can be made with less formal work-based education programs being developed in other unions.

\section{THE PROGRAM}

The education program comprises sixteen modules ranging from organising skills; research, advocacy and communication skills; union history; corporate campaigning; industrial law and political consciousness. Participants are expected to complete formal workrelated assessment in order to satisfy the module requirements, and become eligible for an increase in pay. However, there has been a low number of assessment exercises completed and some resistance to the idea of linking pay increases to course completion.

Over the period between the new program's start and the research commencing nine different courses were delivered. In all, allowing for those courses that were conducted more than once, sixteen courses were delivered. Ninety-six officials/officers, or forty-seven per cent of the union's staff, participated in at least one course, and fifteen per cent attended three or more courses.

At the same time as the MU was developing its program, parallel work was being done by the Australian Council of Trade Unions (ACTU) to develop an accredited Certificate Level IV in Trade Unionism based on a set of competencies that was eventually registered by the Business Services Industry Training Advisory Board (ITAB). In addition the union movement's traineeship program known as 'Organising Works' rests on the Certificate level competencies. The MU was interested in knowing if its program would satisfy the requirements of that Certificate without compromising the integrity of its program. ${ }^{1}$

\footnotetext{
1 An earlier project mapping the MU's program against these official competencies had been completed and submitted to the union and informed this evaluation. (Brown \& Boughton 2003)
} 


\section{METHODOLOGY}

In planning the research and evaluation strategy the researchers set out to examine the program's acceptance, effectiveness, assessment mechanisms and options for program redesign. The main method of data collection was a structured interview conducted by telephone with three groups of officials and officers. Participants in the survey were randomly selected from the union's staff with an aim of achieving a balance of state and divisional representation, and a proportional representation of different classifications and gender. According to the union's attendance data almost three quarters of all course participants were organisers with a further twenty percent being research and legal officers. Those responding to the survey, while mirroring this divide, represent a lesser proportion of organisers (45\%) and a higher proportion of research / legal officers (36\%). The survey included officials and officers working in all states as well as the National Organising Units and the National Offices located in Sydney and Melbourne.

In all thirty-five interviews were held with course participants (22), course non-participants (10), and senior staff occupying supervisory positions (3). This sample group represented one sixth of the union's staff.

\section{EXPECTATIONS AND PERCEPTIONS OF COURSE VALUE}

The most commonly taken course was Organising 2 (12 people), Industrial Bargaining \& Corporate Campaigning (9 people), Organising 1 (8) and Negotiation and Critical Analysis (8). The 12 people taking Organising 2 took 35 courses in all, but in general the fewer people doing a course the fewer are the total courses done by those participants-on average, about 3.0 courses per participant. There is little surprising about that. 
More significant is the fact that the courses differ in the relative experience of those taking them, as reflected in their years in the union — Industrial Law \& Practice 1 has the highest value (9.3 years compared to the overall average time in the union of 4.5 years). The two Organising courses, if they were meant to reach those with less experience, are certainly doing so, and the general pattern is that respondents with less experience in the union are taking more courses than those with the bulk of longer service.

The participants were significantly younger and less experienced than the non-participant, with an average of 4.5 years in the union (ranging from 16 years to 6 months) compared to 13.2 years for the non-participants, half of whom had been in the union for over 12 years, and one for 31 years. The sample therefore represents a broad range of union experience, as it does a range of states and types of positions within the union.

The main reason staff did a course was 'the opportunity to broaden skills (15 or 68\%) rather than 'interest in the subjects' (5 or $23 \%$ ) or 'somebody told me to do it' $(2,9 \%)$. Other reasons for participating, 'wanted a recognised certificate', or 'to advance within the union', barely rated.

Participants were asked about the main benefit they expected from the course(s) they did in 2004. Their responses overwhelmingly favoured 'skills for union work-administration, organising' (73\%) with fewer nominating 'understanding union politics' (23\%) or 'consciousness raising of members' (18\%). Significantly there was not a single response for a 'pay increase for completing subjects' and other reasons amounted to $14 \%$ of responses. 
Overall, participants rated the course as ‘very much’ meeting their expectations (73\%) with a minority expressing less favourable reactions. When asked to rate the importance of a set of goals for the program, participants regarded the most important aims were to 'focus on challenges facing union membership', and 'help officers perform their jobs better', while the aims to 'lead to a recognised qualification' and 'to emphasise career development of officers’ were rated as least important.

When participants were asked, "what did you most value about the program experience?” the answers could be grouped under four headings with one standing out above the others.

There was a very strong feeling that the most benefit came from meeting other officials and developing networks. This informal learning was expressed in similar terms by different respondents - 'Learning from other organisers. You pick up from other organisers more than anything' (LM17, Organising Unit, $4^{2}$ ); 'Networking, discussing problems in the field and finding solutions to those problems' (LM7, State officer, 2.5); 'Interaction with other organisers, experienced and inexperienced. It showed up the less experienced people, where they were coming from. They learnt from the experienced.' (LM15, Organiser, 1.5)

Learning from others was also associated with the formal content of the courses. For instance, learning new ways to organise a new workplace was complemented by 'brainstorming with others with similar experience' (LM14, Organiser, 6) presenting 'the opportunity to learn with peers’ (LM3, Industrial Officer, 2.5).

2 This refers to the coded respondent, the unit where they worked or their job classification, and the numbers of years in the MU 
Six respondents saw developing new knowledge through the formal content of the courses as having the most value. One industrial officer new to the union at the time of attending looked back a year later and described the course as 'providing a shot-in-the-arm. It was motivational, I was able to discuss issues with other organisers'. It was 'intellectual selfcare - able to get away from the day-to-day and reflect on what (we) were doing.' (LM2, Industrial Officer, 1) Another organiser who had attended multiple courses said he 'was able to broaden his horizon and develop self-awareness'. (LM16 Organiser, 6)

The opportunity to learn from and with peers, to meet other staff and develop new networks, appears to be regarded as equally if not more important than the content contained within the courses.

\section{PROGRAM EXPERIENCE AND PERCEPTIONS OF ITS VALUE}

Overall those interviewed thought the courses had been well organised. There was universal agreement among those who attended a course that the educators encouraged participation. In general most (15) found the aims of the course either clear or very clear.

In most cases people felt that the participation of others in the courses was high and remained consistent through the course, although there were some qualifications. The obvious point was made that those who wanted to be in the course and found it interesting participated more fully than others:

people interested in being there participated all the way through. Those that were press-ganged were reluctant and had to be made to participate. (LM2, Industrial Officer, 2) 
There was a positive response to those courses where conversation and exchange was stimulated and where opinions could be freely discussed. One organiser remarked that he 'was fairly pleased that the trainer when asked questions didn't just give his opinion, but opened it up for discussion'. Two people observed that participation stayed high in this course where ‘the discussions were more dynamic' and 'the subject engaging'.

More than two-thirds said they had encountered some difficulty in attending courses, with the single biggest problem being the tension created by being away from the office and keeping up with work while trying to concentrate on the course. There is an expectation from members that the official is still working on an issue, and work builds up while on the course creating a heavy load on return to work.

No problems getting away from the office. It's just the workload - getting ready before you go and the load waiting for you when you return. (AB1, Organiser, 1)

Among non-participants pressures of time were identified by eight of the ten surveyed suggesting this could be a significant reason for them not enrolling:

Some people don't put in for courses because they don't know how to find the time. There is no back-up. They have to be done on top of everything else. Need to delegate resources for replacement. That will never happen, but they need to. (NP4, Industrial Officer, 13)

Surprisingly only two referred to problems associated with courses being cancelled.

Among those who did not participate different reasons were offered. Some saw the program as not being relevant to them. An administration officer said that the program 'didn’t meet any of my needs because the courses were not directly relevant to my job’. (NP6, 6) An office manager had a similar attitude saying that in her opinion the program wasn't 'aimed at administration staff. Don't think they thought about us until they realised we weren’t attending.' (NP2, 3) 


\section{ASSESSMENT EXPERIENCES}

Early feedback about the program suggested that among the most contentious issues were those surrounding assessment. A major part of the survey therefore probed these issues along with recognition of their prior learning (RPL).

Assessment is not highly valued as an outcome of the program, even though this was a central feature of the new program and important in the eyes of the union's leadership group. Rather it was the interactive and participatory aspects that were most valued-the sharing of experience and information with peers, discussion with other organisers, the networking and reflection on their practices, the 'coming together with a range of officers and officials from different states and regions ... and the opportunity to learn with peers' (Industrial Officer, 2.5).

\section{Attitudes to assessment}

Of the 22 program participants, 14 (or 63\%) came prepared to be assessed, while 16 (including the 10 non-participants surveyed) were not prepared to undergo the process. Some (6 people) changed their attitude deciding not to submit once the course began, though most had no change of heart on the matter. A small minority (4) said they submitted work.

The responses indicated a degree of ambiguity about what assessment entailed—for example, an impression, or misunderstanding, that assessment would take place on the course itself. A common theme was that is was difficult to find the time to do assignments once back in the workplace and away from the program. Some felt that requirements themselves created difficulties and some were 'morally opposed to do training to get a pay increase' 
(AB1, National Organiser, 1 yr, 3 courses). One of the more vociferous comments expressed both ambiguity and negativity:

I didn't know at the beginning. I said 'here we go, another one'; 'how am I going to get time to do it with all my work'; 'are we back at school again?' You know it's got to be done, but what's the consequence of not doing it? Is it optional? It shouldn't be forced. (AB2, Industrial Officer, 2 years, 4 courses).

When asked whether they submitted, the reasons from those who didn't ranged from the common factor of competing work pressures and 'not getting around to it' to a dislike of the way the process was conducted. For some, the assessment was not geared to their work but focused on organisers.

A strong theme was the 'unrealistic' learning involved compared to learning on the job:

Either I know how to do the job or I don't... Union officials don't do it for the money. You don't learn in class you learn it on the job ... To do an assignment won’t help people to learn. (LM10, Project Officer, 3.5 years, 2 courses)

Others had doubts about the capacity of some to do it, with some people in the organisation labelled 'barely literate'. For some there was a complex of reasons, that taken together with the above comments, suggest that assessment process has to be more flexible:

No, started but didn't finish it. It was only half a module, so would have to do the other half to get some benefit from it. Couldn't afford another four days away... In the assessment you were a driver in campaigns, but I am not a driver, I work at the behest of organisers and union officials. ... (LM10, Project Officer, 3.5years, 2).

Prompted to focus on support and mentoring twice as many people thought there was insufficient help than felt there it was adequate. Those who were positive asserted there was 'definitely support if you took the effort'-for example, where a course tutor rang them or looked at their drafts. Others affirming support were more equivocal, seeing or- 
ganisers as getting most support, though the organisers themselves were divided in their views on this. Support was seen as lacking from the education section, and for some, more support came from fellow participants.

Others saw the problem as due to 'the broadness of the course' or the way work swamped their efforts to do the assessment. Negative opinions focused on the unrealistic expectations and lack of support:

Not enough support. In the first course pressure was put on to hand in an assignment by the education department-I was to set the example. I completed the assignment - which was partly hand written due to time issues - and sent it in and never got a reply. (LM7, State Officer, 2 years, 3 courses).

Its one thing our union lacks, any kind of mentoring, especially for new people. Not sure who to see or what to ask, or admit you're not up to scratch. But if you do ask people they are helpful. But no one has approached me about not completing any assessment and I'm surprised by that. And I haven't been asked or told to do any more courses. Maybe it's linked, I don’t know. (AB1, Organiser, 1 year, 3 courses).

Opinion was evenly divided about 'the kind of assignments' and whether written, oral or other work was required and whether this was negotiable, with 10 positive and 11 somewhat negative. Responses reflected the factor of the wide range of abilities found within the union and brought out the tensions between research and organising positions. There was for some, a contradiction in requiring written assessment of skills that were clearly in evidence 'on the shop-floor':

You had to organise a new workshop. I had already organised two workshops in record time, but they would not recognise that. When I came on board I organised two sites in the first two weeks. Was thought a whiz kid, maybe had a natural aptitude or something. Then at the course they say you need to pick your site, what you have to do. What do you have to do to prove to them? Most officials have organized shops. (LM10, Project Officer, 3.5 years, 2 courses). 
While personally at ease because of a university background, some saw the 'need to look at other means, be more flexible because some people have learning difficulties, that is, limited literacy skills ... writing a 3 page document for some can be very hard. (AB3, Research Officer, 2.5 years, 4 courses). Imposing inflexible process on shop floor organisers highlighted the literacy barrier.

Half the participants (11 or 50\%) felt that the assignments were appropriate in reflecting ‘the industrial reality’ of the union. One participant felt they were 'absolutely appropriate ... the trainers have focused on the challenges facing us and used assignments to face up to overcoming the challenges (AB3, Research Officer, 2.5 years, 4 courses). Others found they were able to use the information and techniques suggested—one assignment required the course participants to 'do a company search and map the demographic of an industry. It was good for organisers to be able to do this themselves when a researcher couldn't do it for them' (National research officer, 1, 1).

The more equivocal to negative responses thought some assignments less and setting aside a few responses that reiterated criticism of the 'pay-for-accreditation' principle, some issues emerging were the disjunction between what could be assessed on-course instead of afterwards, and the need to base courses on an analysis of the work capabilities of organisers and delegates. Though only 5 people responded to a question asking what was learned from any assignment submitted, they have implications for how assessment might be designed in the future. The outcomes for these participants reflect the goals and strengths of particular courses:

I learnt how to interpret a document in critical analysis. In Negotiation, I found negotiating becomes a whole lot easier the better organised you are. If you had a wellorganised workplace it didn't matter if you were a shit negotiator. If workers were 
hot on an issue you could do it. Learned how to organise, how to get the point across and when you have a decision let the members decide. (LM15, Organiser, 1.5 years, 2 courses).

\section{Recognition of prior learning}

Participants were asked if RPL was an option, whether they applied and what was their attitude. Most were aware of the option, but a common theme of responses was that the union was not serious about the process or that it was not a realistic one, holding out the possibility of recognition but something that was unlikely to be achieved. Others simply did not get organised to submit documentation or thought that the process was too complicated to be worth the effort.

Some felt that recognition should be hard to get in order that 'long-time organisers' should be forced to do courses to 'open their heads and get them to talk' (new organiser, 1.5 years). Another who was in fact a long-time organiser 'decided to go and do the courses because after sixteen years he had never been to a course' and thought that what was expected now was 'was totally different from the past and [his work experience] would not have been relevant. (LM13).

It is not clear that participants understood the rationale for RPL and it seems that guidelines were not communicated clearly and fully to possible applicants. An isolated but pointed criticism of the process was a reflection on the program and the union as a whole. An experienced industrial officer, who had not participated in the program, saw an underlying problem — the union's failure to analyse its own work as a basis for organising training that would 'take into consideration what people are doing in their work': 
Courses [are] designed so that in order to get a pay rise you have to do units that are irrelevant. One of the biggest problems is that there is no coordination of work. Some unions have a meeting where strategic plans are made and everything is coordinated to that. There is training in absence of coordinating and strategic direction. For example one of my workers would have to do a course on organising, but she never has the opportunity to organise ... (NP4, Industrial Officer, 13 years).

\section{Affect of assessment issues on course perceptions}

Did assessment issues colour respondents' perceptions of the course and its value? A good majority (14 or 63\%) felt that assessment issues had not detracted from a course that they generally felt to have been valuable, and they expected it as part of the experience. The other participants felt that assessment had limited their outcomes from the course they did, or in stronger terms, had reduced the credibility of the course because it was not 'taken seriously' but was 'just hoops to jump through' or had left 'a bitter taste’ from the RPL process (Industrial Officer 2.5 years, 3 courses). For these participants, the assessment process 'created a negative slant on everything' (LM12, Organiser, 15 years, 1 course) or it 'had a pretty dramatic effect. The way they did the assessment degraded the course. People on the courses wanted to learn, to participate'. (LM13, Organiser, 16 years, 5 courses). Thus there is quite a disjunction of experience in those who felt the assessment to be fruitful and those who found it less than affirming.

The last question about assessment aimed to draw out suggestions for encouraging more people to participate in assessment. There were quite a number of specific ideas and they can be summarised ion three main responses:

- Pay increments do not make someone want to do assignments,

- There is a need for designated time away from the job to complete the process, and

- The challenge of literacy levels among older officials needs to be acknowledged. 
This issue is not a simple one, since it is not only about what capabilities are needed to perform an assessment task, since developing certain kinds of literacy (eg legal literacy) are important goals of the program. Thus the literacy issue raises the question of what 'literacies', including political literacies, the union wishes to develop and promote by establishing the program in the first place, going to the heart of the program's aims, structure and educational practices.

There were strong messages about making assessment more flexible and adapted to the everyday demands of union work, recognising that much of this is not desk-based. These included:

- Have assessment, or a large proportion of it undertaken during the course,

- Recognise the realities of work pressures on completion of assignments,

- Use oral (viva voce) or written tests or a combination,

- Provide more supportive processes for completing assessed work in general,

- Smaller tasks with more follow up, including a course to work on assignments,

- Acknowledge that different individuals will have different priorities,

- Tailor assessment to the individuals so it applies to the context of their own work.

This is not merely about participants wishing to avoid the heavy literacy demands of written assignments, it can also be heard as a demand for an educational rationale that is more experience-based and a better fit with the character of contemporary work for the union.

Finally, the assessment process, and this needs to be seen as including the RPL application process, emphasised the importance of mentoring and support discussed earlier. Attitudes to assessment were not initially negative, but made more so by the conflict of the time demands of assessment with work pressures. That only a few participants submitted as- 
signments can be attributed to their perceived inflexibility and inappropriateness to the work context where a combination of factors was at work to discourage submission.

\section{OPTIONS FOR PROGRAM REDESIGN}

Respondents were generally very positive in response to a question asking if the program was in need of basic change. Even where people identified some area that needed change or attending to they were mostly supportive of the overall program.

The real changes need to be around how assessment is carried out. It has been an incredibly positive experience. I've always walked away enthused. The basics are really good. (AB3, Research Officer, 2.5)

This view is backed up by a number of responses along the lines of the program is on the whole good and not needing basic change.

However, there remains some confusion about the nature and objectives of the program, which is understandable given that the program aims to be different to previous education programs of its type. One of the main objectives is to develop skills especially in the area of organising and growth in the context of the current industrial and political climate. This conception of skill is of a particular kind that is most associated with the MU's conception and practice of organising. However, some staff are looking for development of very specific work related skills related to management or advocacy in the Industrial Commission.

While the sixteen modules that make up the program should be capable of addressing these expectations it does raise the possible need to provide more targeted or niche training opportunities. A legal officer suggested that there is a 'need for several programs'. Another organiser pointed to people's different learning styles and working patterns and the need to take this into account when arranging education activities. This organiser suggested that 
the length of the course was felt differently physically according to the nature of a person's job:

It goes for a week and maybe office-based staff find it easier. But for organisers who are in and out of a car and the office, sitting down for a week is very hard. It's draining and hard to just sit. I found myself getting up to walk around. (AB1)

\section{Areas for improvement}

Some staff, although small in number, expressed strong criticism of the program. Three staff when approached to be involved in the survey refused to even be interviewed with two stating it was because of their opposition to the program. When offered the opportunity to have their views recorded and reported on they still refused to participate.

Most responses however focussed on ways of improving the program. Taking up the earlier theme of peoples' disposition to learn together two referred specifically to the benefits of meeting people from other states, with one commenting not only about learning together but the need to facilitate more informal support systems especially for new staff:

Others thought that providing support for staff while they were away from their job would improve participation and completion while recognising that there are constraints that might prevent this occurring.

Support for people to participate is limited. Given that in most cases the union is running on bare bones as far as the number of organisers is concerned, it is difficult to get people to push up for you while you're away. There were eight courses last year I got a letter to attend, but could not go to because of the amount of work. (LM14)

These comments reflect a desire to participate in the program:

[it] should be made easier to attend. There should be people delegated to cover organisers when doing the course. Ninety nine per cent of organisers want to do courses. A way has to be found to free their time up. (NP8) 
A third area suggested for improvement again took up the idea of recognising different learning needs and experience of staff.

Twenty different people at twenty different levels turn up. Needs to be fair dinkum and strategic decisions on who do we want on these courses. For example office staff doing organising and industrial negotiating courses. Why is the union sending them; it is not part of their job. (LM3)

A Learning Needs Analysis needs to be done with face-to-face discussions with each person and also asking the state secretary what they think each person could learn from. (NP4, non-participant)

Meeting these different needs presents a challenge for a single program designed to meet the needs of a large number of staff within a single organisation.

Not everyone took the opportunity to make a final comment but among those who did there was very strong support for the union's decision to initiate the national education program.

It's an overwhelmingly positive experience for me and I think that would be if you'd been here 6 weeks or 20 years. (AB3)

There is a strong belief that training is an important activity for the union to be involved in and equally important for staff to develop and improve their skills and knowledge.

People should understand that when the union takes you on there is training. Otherwise you are dropped in and that's where you stay for fifteen or sixteen years. There should be more political stuff about where we sit politically on issues in our society. Otherwise the new people can't answer questions, they're asked: shouldn't work and politics be kept separate, and they can't answer. (LM13)

One organiser with many years experience in the union believes that the program represents an important change:

Being an organiser for six and a half years and a shop steward for nine years before that I know that you can never have enough training. You get initiative. I've spoken to past and current union officials and the union expected you to provide without 
training. There is a reluctance from long-term union officials. Being a union official is a unique job and training helps. You know the core values of the working class and it helps you deliver them. (LM16)

The final word should be left to an organiser with one year's experience in the union:

I hope I didn't come over as too negative. Training is good, I think training is good. I just don’t like the link to pay. You never stop learning. (AB1)

\section{CONCLUSIONS}

It is possible to highlight a number of key issues emerging from the research:

Participants expressed a strong preference for learning from and working with peers and other officials and officers from other branches and divisions. This informal learning preference suggests that MU staff see learning as a social activity and value it as a collective experience, and suggests a need to find ways to support this preference within the program.

Support for the program is higher among those who have participated in the program. This is especially the case for newer staff. Those who attended courses in the early stages of their employment with the union commented on the benefits gained from early exposure to other officials and the union's history, current positions and expectations.

Assessment and RPL are burning issues with strong feelings being expressed by respondents. Building in more flexible assessment options would be received favourably. An option for making assessment a core activity while in the course would partly address issues of workload, but also allow participants to draw on peer skills and experience.

There is some confusion and misunderstanding about the terms RPL and Advanced Standing. RPL is essentially assessing prior experience, while Advanced Standing is about recognising previous qualifications. This is an issue that has generated some ill will among those interviewed and led some to decide not to participate in the program. There is a need to clarify both the process and communication of RPL and Advanced Standing. 
Literacy issues were referred to by a number of respondents and appears to be an underlying issue that needs addressing. In particular, assessment needs to be designed to develop appropriate literacy skills as an integral part of the learning and assessment.

The issue of linking pay to course completion was the hottest issue among those interviewed generating ill-will toward the union from a number of officials and officers. There is a potential for this issue to undermine staff morale unless addressed.

Many staff, especially organisers, express frustration at being unable to complete course requirements and manage workloads while at the course or soon after returning to work.

There is a challenge in meeting the varied learning needs of staff in different positions with diverse experiences, skills, educational and working backgrounds. Participants suggested that to date the union has adopted a 'one size fits all' approach that needs to be reconsidered, raising the question of how to develop a program that meets these different needs.

There is support among staff for training in general and for the program in particular.

Finally, as union movements across the world, grapple with declining union membership, shifts in patterns of employment and industry growth, and are confronted by aggressive employer and government agendas aimed at squeezing the role of unions, new practices of organising and education are emerging.

How education can assist in developing new understandings and strategies has been the focus of research in a number of countries in recent years. (ACTU 1999, 2003, 2004; Bronfenbrenner et al 1998; Burke et al 2002; Byrd \& Nissen 2003; Carter \& Cooper 2002; Delp et al 2002; Fletcher 1998; Griffin \& Moors 2004; Milkman \& Voss 2004; Widenor, \& Feekin 2002; and Yates 1998.) A pressing research need though is to continue to detail 
specific union education programs and interventions and theorise how formal and informal learning can assist unions in these times. Close studies of the practice of individual unions can contribute to this knowledge. 


\section{References}

Australian Bureau of Statistics (ABS) (2002) Employee Earnings, Benefits and Trade Union Membership, Australia, Cat No. 6310.0, Canberra, AGPS

Australian Bureau of Statistics (ABS) (2003) Manufacturing: Trade Union membership in the manufacturing industry Australia, Canberra, AGPS

Australian Council of Trade Unions (1999) Unions@work: the challenge for unions in creating a just and fair society, Melbourne, ACTU

Australian Council of Trade Unions (2003) Future Strategies: unions working for a fairer Australia, Melbourne, ACTU

Australian Council of Trade Unions (2004) The way forward: ACTU strategies for union delegates, Melbourne, The Union Education Foundation

Ball, M. (2003) Considering trade union education as a community of practice, in International Journal of Lifelong Education, 22:3, May-June, 297-310

Bronfenbrenner, K., Friedman, S., Hurd, R., Oswald, R. and Seeber, R. (eds.) (1998) Organising to win: new research on union strategies, Ithaca, ILR Press

Brown, T. \& Boughton, B. (2003) AMWU Organiser Development Program: Interim Report on Mapping Exercise, report submitted to the AMWU, October

Burke, B., Geronimo, J., Martin, D, Thomas, B., \& Wall, C. (2002) Education for Changing Unions, Toronto, Between the Lines

Byrd, B. \& Nissen, B. (2003) Report on the State of Labor Education in the United States Los Angeles, UCLA Berkeley Labor Center

Carter, B. and Cooper, R. (2002) The organizing model and the management of change: a comparative study of unions in Australia and Britain, /Industrial Relations, 57:4, Fall, 712-740

Corrie, J. (2003) 'The 1990s merger process of the Australian Manufacturing Workers Union: from eggs benedict to tea and toast', in Transforming Labour: Work, workers, struggle and change, proceedings of the Eighth National Labour History Conference, Brisbane, 3-5 October, 97-104

Crosby, M. (2005) Power at work: rebuilding the Australian union movement, Sydney, Federation Press

Delp, L., Outman-Kramer, M., Schurman, S. and Wong, K. (eds) (2002) Teaching for Change: popular education and the labor movement, Los Angeles, UCLA Center for Labor Research and Education

Fletcher, B. (1998). Labor education in the maelstrom of class struggle, in E. Wood, P. Meiksins, \& M. Yates (eds.) Rising from the Ashes? Labor in the age of global capitalism. New York, Monthly Review Press, 110-123

Griffin, G. and Moors, R. (2002) 'Organising works: objectives, evolution, outcomes', in I. McAndrew and A. Geare (eds) Proceedings of the $16^{\text {th }}$ AIRAANZ Conference, Queenstown, 180190

Griffin, G. and Moors, R. (2004) 'The fall and rise of organising in a blue-collar union', Journal of Industrial Relations, 46:1, March 39-52

Kopsen, S. \& Larsen, S. (2002) Learning in a trade union, www.oise.utoronto.ca/CASAE/cnf2002/2002_Papers/kopsen\&larsson2002w.pdf

Milkman, R. \& Voss, K. (eds.) (2004) Rebuilding Labor: organizers and organizing in the new union movement, Ithaca, ILR Press/Cornell University Press

Sutherland, D. (2003) Personal conversation with MU National Education Officer

Widenor, M. \& Feekin, L. (2002). Organiser training in two hemispheres: the experience in the USA and Australia, in B. Spencer (ed.). Unions and Learning in a global economy: international and comparative perspectives, Toronto, Thompson Educational Publishing, 100-111.

Yates, M. (1998). An Essay on Radical Labor Education. Cultural Logic, 2(1), Fall, http://eserver.org/clogic/2-1/yates.html 